\title{
ANTIMICROBIAL ACTIVITES OF COW DUNG EXTRACTS AGAINST HUMAN PATHOGENS
}

\author{
S. RAJESWARI, E. POONGOTHAI, N. HEMALATHA*
}

\author{
Applied Microbiology Laboratory, Department of Microbiology, Periyar University, Periyar Palkalai Nagar, Salem-11
} Email: aarthihema2004@gmail.com

Received: 19 Jul 2016, Revised and Accepted: 20 Aug 2016

\begin{abstract}
Objective: For control of microbial infections and diseases, various synthetic drugs and chemical formulations are currently in use. But due to the problem of microbial drug resistance, new alternative synthetic drugs have been explored. Similarly, antimicrobial activities of so many natural products have also been explored.
\end{abstract}

Methods: In this various study extracts of cow dung possessed antimicrobial property against human pathogens like Klebsiella pneumonia and Escherichia coli.

Results: The Indian cow dung extracted possessed superior antimicrobial activity than other cow dung types and showed antimicrobial property against all the test microorganisms. Since cow dung and buffalo dung are abundant in nature, which make the process cost effective with processing ease and thus are a promising solution for a variety of health problems in the near future.

Conclusion: The medicinal properties of these cow dung and buffalo dung can be exploited to formulate drugs for several diseases caused by antibiotic resistant pathogenic microorganisms.

Keywords: Cow dung, Klebsiella pneumonia, Escherichia coli, Antimicrobial activity

(C) 2016 The Authors. Published by Innovare Academic Sciences Pvt Ltd. This is an open access article under the CC BY license (http://creativecommons.org/licenses/by/4.0/) DOI: http://dx.doi.org/10.22159/ijcpr.2016v8i4.15268

\section{INTRODUCTION}

In India, cattle's rearing is a tradition in the country and intimately limited to the agricultural economy. Different products obtained from cow milk, ghee, curd, urine, and dung are used widely in a number of ayurvedic formulations. Cow dung is traditionally used as organic fertilizer in Indian sub-continental farming for centuries. The addition of cow dung increases the mineral status of soil, enhances the resistance of plant against pests and diseases; stimulate plant growth and other beneficial activities such as sulpho oxidation and phosphorus solubilization [1].

The Hindu Vedas say that the cow is holy and should be worshiped. In India, cows are very important animal resources and are highly useful in agriculture and dairy industry [2]. Panchagavya is a term used to describe five major substances, obtained from cow, which include cow's urine, milk, ghee, curd and dung. All the five products possess medicinal properties against many disorders. This kind of treatment is called Panchagavya therapy or cowpaths [3]. Cowpathy is an old system of medicine mentioned in ancient Indian literature (Ayurveda) as Panchagavya Chikitsa. The ayurvedic medicines of animal origin are mainly prepared from Panchagavya which boost up the body immune system and makes the body refractory to various diseases [4]. Although some Indian literature mentioned the medicinal property of cow excretion, only a few were proved. Several useful properties of cow urine got confirmed by researchers patent also. But there is no report available on antimicrobial activity of cow dung.

Cow dung is basically the rejects of herbivorous matter which is acted upon by symbiotic bacteria residing within the animal's rumen. The resultant faecal matter is rich in minerals. Cow dung is the undigested residue of plant matter which has passed through the animal's gut. The resultant faecal matter is rich in minerals. Cow dung is comprised of organic matter including fibrous material that passed through the cow's digestive system, among other liquid digesta that has been left after the fermentation, absorption and filtration, then acidified, then absorbed again. The chemical composition mostly carbon, nitrogen, hydrogen, oxygen, phosphorus, etc. with salts, cells sloughed off as the digest a went through the digestive tract, some urea, mucus, as well as cellulose, lignin and hemicellulose.
The addition of cow dung increases the mineral status of soil, enhances the resistance of plant against pests and diseases; stimulate plant growth and other beneficial activities such as sulphur oxidation and phosphorus solubilization. Normally, Composition of cow dung is about $80 \%$ water and supports a matrix of undigested plant material that is rich in nutrients, micro-organisms, and their byproducts. Cow dung microflora contains an abundant number of bacilli, lactobacilli and cocci and some identified and unidentified fungi and yeasts [5].

Escherichia coli, is a Gram-negative, facultative anaerobic and nonsporulating bacteria. Escherichia coli use mixed-acid fermentation in anaerobic conditions, producing lactate, succinate, ethanol, acetate and carbon dioxide [6]. It is a common kind of bacteria that lives in the intestines of animals and humans and most are harmless. Eating unwashed greens such as spinach, lettuce or green onions or undercooked beef can cause the infection [7]. The spores are heat, chemical and $\mathrm{pH}$ resistant, the extracts were passed through a membrane filter (Millipore corp; $47 \mathrm{~mm}$ diameter; $0.2 \mu \mathrm{m}$ pore size). Bacterial infections are usually treated with antibiotics. However, the antibiotic sensitivities of different strains of Escherichia coli vary widely. Gram-negative organisms, E. coli are resistant to many antibiotics that are effective against Gram-positive organisms [8].

Klebsiella pneumoniae is a Gram-negative, non-motile, encapsulated, lactose fermenting, facultative anaerobic, rod shaped bacterium found in the normal flora of the mouth, skin, and intestines [9]. Klebsiella pneumonia tends to affect people with underlying diseases, such as alcoholism, diabetes and chronic lung disease. Multiple-resistant Klebsiella pneumoniae have been killed in vivo via intra-peritoneal, intravenous or intranasal administration of phages in laboratory tests. While this treatment has been available for some time, a greater danger of bacterial resistance exists to phages than to antibiotics [10].

With this view, this study focused on the antimicrobial activities of dung extracts of Indian and imported cows and buffalos against human pathogens.

\section{MATERIALS AND METHODS}

\section{Cow dung collection}

Different cow dung (Indian cow, Jersey, Holstein) and buffalo dung were collected in and around Dharmapuri District. 


\section{Culture collection}

The two-gram negative pathogenic strains namely Escherichia coli and Klebsiella pneumonia samples were collected from Gopi hospital; Salem Were collected for this study.

\section{Powdered cow dung}

- $1000 \mathrm{~g}$ of cow dung from Indian cow (Dharmapuri) was collected and shadow dried for $5 \mathrm{~d}$. The moisture content of the cow dung was lower than the other types. The dried cow dung was powdered. The powdered material had a net weight of $290 \mathrm{~g}$.

- $1000 \mathrm{~g}$ of cow dung from Jersey was collected and shadow dried for $5 \mathrm{~d}$. The moisture content was high when compared to cow dung from Indian cow. The dried cow dung was then powdered. The powdered material had a net weight of $250 \mathrm{~g}$.

- $1000 \mathrm{~g}$ of cow dung from Holstein was taken and shadow dried for $5 \mathrm{~d}$. The moisture content was high when compared to cow dung from Sindhu. The dried cow dung was then powdered. The powdered material had a net weight of $220 \mathrm{~g}$.

- $1000 \mathrm{~g}$ of buffalo dung was taken and shadow dried for $5 \mathrm{~d}$. The moisture content was high when compared to cow dung from Jersey. The dried buffalo dung was then powdered. The powdered material had a net weight of $190 \mathrm{~g}$.

\section{Preparation of cow dung extracts}

$100 \mathrm{ml}$ of acetone and ethanol was added in $10 \mathrm{~g}$ of powdered different cow dungs (Indian cow, Jersey, Holstein and buffalo dung) in a conical flask and it was kept in a rotary shaker for $3 \mathrm{~d}$. The extract was then filtered using Whatman No 1 filter paper and stored in a vial for future use.

\section{Preparation of the disc containing cow dung extract}

The empty discs were impregnated with $50 \mu \mathrm{l}(2 \mathrm{mg} / \mathrm{disc})$ of acetone extracts of cow dung from Indian cow, Jersey, Holstein and buffalo dung separately and dried in the oven. Similarly, the empty discs were impregnated with $50 \mu \mathrm{l}(2 \mathrm{mg} / \mathrm{disc})$ of ethanol extracts of cow dung from Indian cow, Jersey, Holstein and buffalo dung separately and dried in the oven. This process was repeated until the disc was completely saturated with the extract. The disc was then used to study the antimicrobial activity of cow dung extracts against human pathogens [11].

\section{Antibiotic sensitivity test}

Kirby-Bauer method also known as disc diffusion antibiotic sensitivity testing is a test which uses antibiotic-impregnated wafers to test whether particular bacteria are susceptible to specific antibiotics. It is based on the observation that the degree of inhibition of bacterial growth on agar medium surrounding an antimicrobial compound containing disc correlates with susceptibility to the agent. The zone of inhibition determines whether the organism is sensitive, resistant or intermediate to a particular antibiotic or the antimicrobial compound.

Four to five similar colonies of identified organism from pure culture plates were transferred into the nutrient broth and incubated at 37 ${ }^{\circ} \mathrm{C}$ for $24 \mathrm{~h}$. To determine the antimicrobial sensitivity, the inoculums was spread on the entire surface of the Mueller-Hinton agar plates with the sterile cotton swab. The commercially available antibiotic discs and one disc containing the antimicrobial compound were gently pressed onto the microbe carpeted plate at a distance $15 \mathrm{~mm}$ away from the edge and $24 \mathrm{~mm}$ apart from each other and incubated at $37^{\circ} \mathrm{C}$ overnight (18-24 h). The diameter of the zone of bacterial growth inhibition around each disc was measured and the susceptibility or resistance to the agent in each disc was determined according to the standardized table provided by the Hi-media Laboratories, Mumbai. Antibiotics used were Ampicillin, Amikacin, Chloramphenicol, Gentamycin, Ofloxacin, Vancomycin, Methicillin and Penicillin-G (5).

\section{Phytochemical screening of cow dung extract}

The ethanol and acetone extract of cow dung were used for phytochemical screening. [12,13]

\section{Test for flavonoids}

\section{Lead acetate test}

To $0.5 \mathrm{ml}$ of the extract, a few drops of lead acetate solution were added. The yellow color precipitate was formed in the presence of flavonoids.

\section{Test for glycosides}

A small amount of the cow dung extract was dissolved in $1 \mathrm{ml}$ of water, and then aqueous $10 \%$ Sodium hydroxide solution was added. Formation of yellow color indicated the presence of glycosides.

\section{Test for steroids}

\section{Salkowski test}

To $2 \mathrm{ml}$ of extract, added $2 \mathrm{ml}$ of chloroform and $2 \mathrm{ml}$ of concentrated $\mathrm{H} 2 \mathrm{SO} 4$ and shaken well. Chloroform layer appeared red and acid layer showed greenish yellow fluorescence, in the presence of steroids.

\section{Test for tannins}

To $5 \mathrm{ml}$ of the extract, $1 \mathrm{ml}$ of $10 \%$ lead acetate solution was added. Formation of yellow precipitate showed the presence of tannins.

\section{Test for phenols}

A small quantity of the extract was dissolved in $0.5 \mathrm{ml}$ of $20 \%$ Sulphuric acid solution. Followed by addition of a few drops of $2 \%$ Sodium hydroxide solution, it turned blue in the presence of phenols.

\section{RESULTS AND DISCUSSION}

\section{Antimicrobial activity}

\section{Antimicrobial activity of cow dung from Indian cow}

Indian cow dung had possessed superior antimicrobial activity than cow dung. All the test microorganisms were sensitive to the Indian cow dung. Ethanol extract of the Indian cow dung had shown antimicrobial activity against the entire test organism, while acetone extract had shown antimicrobial activity against Klebsiella pneumonia and Escherichia coli only. The test microorganisms were resistant to cow dung extract from Jersey. Only the Klebsiella pneumonia was sensitive to acetone extract of cow dung. Other extract had no antimicrobial activity against test microorganisms. Cow dung extract from Holstein had shown antimicrobial activity against Klebsiella pneumonia only. The other two test microorganisms were resistant to cow dung extracts. Both acetone and methanol extract had shown antimicrobial activity against Klebsiella pneumonia. Cow dung extract from buffalo dung had shown partial antimicrobial activity against test microorganisms. The Klebsiella pneumonia was sensitive to acetone extract of buffalo dung, but the same microorganisms were resistant to ethanol extract of the buffalo dung. The Escherichia coli were resistant to ethanol and acetone extract. This shows that the buffalo dung had partial antimicrobial activity (table 1).

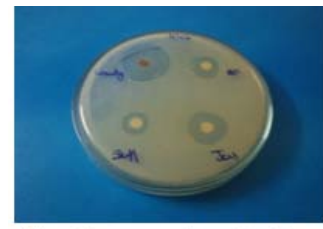

Acetone extracts for K. pneumoniae

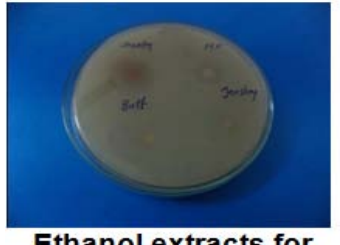

Ethanol extracts for K. pneumoniae

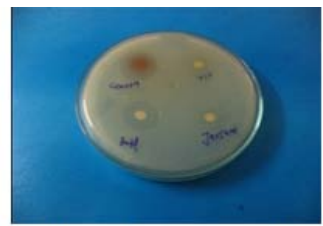

Ethanol extracts for E.coli

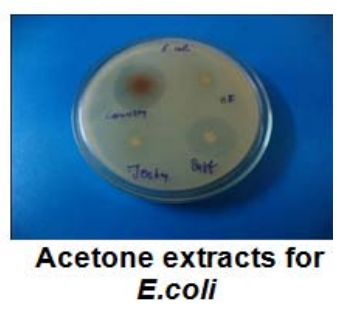

Fig. 1: Antimicrobial sensitivity test 
Table 1: Antimicrobial activities of acetone and ethanol extracts of various cows and buffalo dung

\begin{tabular}{|c|c|c|c|c|c|c|c|c|}
\hline $\begin{array}{l}\text { S. } \\
\text { No. }\end{array}$ & $\begin{array}{l}\text { Test } \\
\text { organisms }\end{array}$ & Antibiotics & $\begin{array}{l}\text { Zone of } \\
\text { inhibition }(\mathrm{mm})\end{array}$ & $\begin{array}{l}\text { Inhibitory } \\
\text { pattern }\end{array}$ & Acetone & $\begin{array}{l}\text { Inhibitory } \\
\text { pattern }\end{array}$ & Ethanol & $\begin{array}{l}\text { Inhibitory } \\
\text { pattern }\end{array}$ \\
\hline \multirow[t]{4}{*}{1.} & E. coli & Ampicillin & 20 & $\mathrm{~S}$ & CAE(I) $20 \mathrm{~mm}$ & $\mathrm{~S}$ & CEE(I) $16 \mathrm{~mm}$ & $\mathrm{~S}$ \\
\hline & & Amikacin & 24 & $\mathrm{~S}$ & CAE(J) No zone & $\mathrm{R}$ & CEE(J) No Zone & $\mathrm{R}$ \\
\hline & & loramphenicol & 22 & $S$ & $\begin{array}{l}\text { CAE(H) No } \\
\text { Zone }\end{array}$ & $\mathrm{R}$ & $\begin{array}{l}\text { CEE(H) No } \\
\text { Zone }\end{array}$ & $\mathrm{R}$ \\
\hline & & & & & BAE $16 \mathrm{~mm}$ & $S$ & BEE $18 \mathrm{~mm}$ & $S$ \\
\hline \multirow[t]{4}{*}{2.} & Klebsiella & Gentamicin & No zone & $\mathrm{R}$ & CAE(I) $22 \mathrm{~mm}$ & $\mathrm{~S}$ & CEE(I) $18 \mathrm{~mm}$ & $S$ \\
\hline & pneumonia & Ofloxacin & No zone & $\mathrm{R}$ & CAE(J) $16 \mathrm{~mm}$ & $\mathrm{~S}$ & CEE(J) No zone & $\mathrm{R}$ \\
\hline & & Vancomicin & 20 & $\mathrm{~S}$ & $\mathrm{CAE}(\mathrm{H}) 20 \mathrm{~mm}$ & $\mathrm{~S}$ & CEE(H) $18 \mathrm{~mm}$ & $\mathrm{~S}$ \\
\hline & & & & & BAE $20 \mathrm{~mm}$ & $\mathrm{~S}$ & BAE No zone & $\mathrm{R}$ \\
\hline
\end{tabular}

Table 2: Phytochemical analysis of acetone and ethanol extract of different cow dung

\begin{tabular}{|c|c|c|c|c|c|c|c|c|c|}
\hline \multirow[t]{3}{*}{ S. No. } & \multirow[t]{3}{*}{ Phytochemical } & \multicolumn{8}{|c|}{ Extract } \\
\hline & & \multicolumn{4}{|c|}{ Acetone } & \multicolumn{4}{|c|}{ Ethanol } \\
\hline & & I & $\mathbf{J}$ & $\mathbf{H}$ & B & I & $\mathbf{J}$ & $\mathbf{H}$ & $\mathbf{B}$ \\
\hline 1. & Flavanoids & + & + & + & + & + & + & + & + \\
\hline 2. & Glycosides & + & + & + & + & + & + & + & + \\
\hline 3. & Steroids & + & + & + & + & + & + & + & + \\
\hline 4. & Tannins & + & + & + & + & + & + & + & + \\
\hline 5. & Phenols & + & - & - & - & + & + & - & + \\
\hline
\end{tabular}

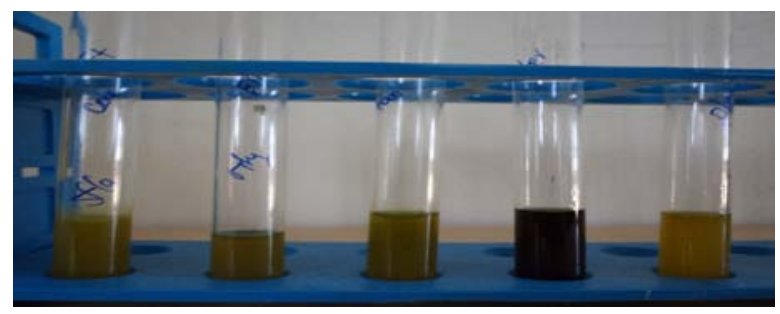

Phytochemical analysis of acetone extraction

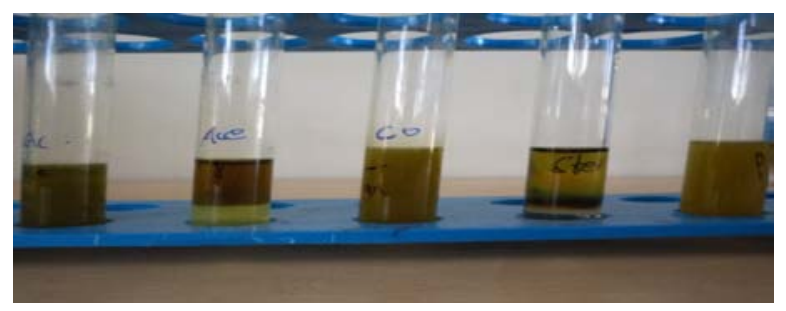

Fig. 2: Phytochemical analysis of ethanol extraction

\section{DISCUSSION}

In Indian Vedas, the cow is considered the most valuable and religious animal of Hindus. In India, cows are a very important animal and useful in agriculture and dairy industry. The cow dung has been used as organic fertilizer and in the production of biogas. The evaporated extract of cow dung is called "Dalang" or "Dalam" in northeast Nigeria and in some part of Northem Cameroun and has been used as soup condiment and in the treatment of infections. Indian cow, jersey, Holstein and buffalo a different healthy cows Cow dung was collected in the early morning from cattle breed of dharmapuri. Cow dung was also put for shed dried. $1000 \mathrm{~g}$ of different cow dung was collected and shadow dried for $5 \mathrm{~d}$. The dried cow dung was powdered. The powdered material $100 \mathrm{ml}$ of acetone and ethanol was added in $10 \mathrm{~g}$ of powdered different cow dungs (Indian cow, Jersey, Holstein and buffalo dung) in a conical flask and it was kept in rotary shaker for $3 \mathrm{~d}$. The extract was then filtered using What man No 1 filter paper and stored in vial for future use the cow dung extraction procedure was followed by [14] Phytochemical analysis was performed by each cow dung extract present the flavonoids, Glycosides, tannins, saponins and phenols this result was similar to [15] which reports these phytochemical compound are present the cow urine. The antimicrobial activities of disc diffusion technique at different cow dung extract against $K$. pneumonia and E. coli. Indian cow dung extracts were activity against the both pathogens in this result are similar to [16] which report that the cow dung extract was inhibition zone of Staphylococcus aureus, Bacillus subtilis and Escherichia coli.

\section{CONCLUSION}

From the experiment conducted it was concluded that the various extracts of cow dung possessed partial antimicrobial property against human pathogens. The cow dung from various cow had antimicrobial property against klebsiella pneumonia. Besides the Indian cow dung extracts possess superior antimicrobial activity than other cow dung and that shown antimicrobial property against all the test microorganisms. Since cow dung and buffalo dung are abundant in nature, cost effective and easy to be processed, they are a promising solution for a variety of health problems in the near future. The medicinal properties of these cow dung and buffalo dung can be exploited to formulate drugs for several diseases caused by antibiotic resistant pathogenic microorganisms.

\section{CONFLICT OF INTERESTS}

\section{Declare none}

\section{REFERENCES}

1. Naskar Sethuraman SK, Ray P Rc. Sprouting in plants by cow dung slurry. Validation of Indigenous Technical Knowledge in Agriculture Extension. Indian Council of Agricultural Research; 2003. p. 197-201.

2. Jonker JS, Kohn RA. Using milk urea nitrogen to evaluate diet formulation and environmental impact on dairy farms. Sci World J 2001;1:852-9.

3. Dhama K, Rathore Rajesh, Chauhan RS, Tomar Simmi. Panchgavya (Cowpathy): an overview. Int J Cow Sci 2005;1:20-2.

4. Chauhan RS, Lokesh Singhal. Harmful effects of pesticides and their control through Cowpathy. Int J Cow Sci 2006;2:61-70.

5. Bharti Sharma, Maneesha Singh. Isolation and characterization of bacteria from cow dung of desi cow breed on different morpho-biochemical parameters in Dehradun, Uttarakhand, India. Int J Adv Pharm Biol Chem 2015;4:276-81.

6. Garg SK, Anita Bhatnagar. Effect of different doses of organic fertilizer (cow dung) on pond productivity and fish biomass in still water ponds. J Appl Ichthyol 1999;15:10-8.

7. Singh Chandra Shekhar, AK Sinha, Singh Balraj, MP Sinha. Effect of cow urine distillate (CUD) on fertility, hatchability and quality of desi poultry eggs. Int J Cow Sci 2007;3:11-3.

8. Muthukumaravel K, A Amsath, M Sukumaran. Vermicomposting of vegetable wastes using cow dung. E J Chem 2008;5:810-3. 
9. Ravi Kant Upadhyay, Pratibha Dwivedi, Shoeb Ahmad. Antimicrobial activity of photo-activated cow urine against certain pathogenic bacterial strains. Afr J Biotechnol 2010;9:518-22.

10. Nargis Akhter, Most Ferdousi Begum, Shahidul Alam, Md Shah Alam. Inhibitory effect of different plant extracts, cow dung and cow urine on conidial germination of Bipolaris sorokiniana. J BioSci 2006;14:87-92.

11. Arunkumar Sathasivam, M Muthuselvam, Rajasekran Rajendran. Antimicrobial activities of cow urine distillate against some clinical pathogens. Global J Pharmacol 2010;4:41-4.

12. WB Sounders. London, Evans. WC Tease. Evans Pharmacognosy. 15th Edition; 2000. p. 3-4, 488-491.

13. Harborne JB. Phytochemical methods; a guide to modern techniques of plant analysis. 2nd Edition. London New York; 1973.

14. Swati H Patel, Jigar V Suthar, Rajesh K Patel, Urvi S Zankharia, Vishakha R Jani, Kanagee N Gajjar. Antimicrobial activity investigation of Aegle marmelos, Couroupita guianesis, Manilkara hexandra, Cow Urine and Dung. Res J Pharm Biol Chem Sci 2015;6:1014-22.

15. K Rajapandiyan, S Shanthi, AM Murugan, G Alagu Muthu, AJA Ranjit Singh. Azadirachta indica-cow urine extract, a novel controlling agent towards clinically significant multi-drug resistant pathogens. J Appl Pharm Sci 2011;1:107-13.

16. M Waziri, JS Suleiman. Analysis of some elements and antimicrobial activity of evaporated extract of cow dung against some pathogens. J Sci Res 2013;5:135-41.

\section{How to cite this article}

- S Rajeswari, E Poongothai, N Hemalatha. Antimicrobial activities of cow dung extracts against human pathogens. Int J Curr Pharm Res 2016;8(4):9-12. 